E-ISSN : 2549-6581

OPEN ACCESS

Journal of Issues in

Artikel Hasil Penelitian

Diterima : 13 Juni 2018

Direview : 02 Juli 2018

Dimuat : Agustus - November 2018

\title{
Pengaruh Konsumsi Susu Sapi Terhadap Penurunan Intensitas Nyeri Dismenore Primer Pada Siswi Jurusan Keperawatan Di SMKN 2 Malang
}

\author{
Devi Febriani $^{1 *}$, Dewi Ariani ${ }^{1}$, Inggita Kusumastuty ${ }^{2}$ \\ ${ }^{\left.1^{*}\right)}$ Program Studi S1 Kebidanan Fakultas Kedokteran Universitas Brawijaya, \\ ${ }^{2}$ Program Studi IImu Gizi Fakultas Kedokteran Universitas Brawijaya \\ E-mail : febrianidevi13296@gmail.com \\ HP : 087834919453
}

\begin{abstract}
Primary dysmenorrhea is a common gynecological disorder among adolescents females without pathological abnormalities. Primary dysmenorrhea usually begins two days before menstruation or during menstruation and lasts up to 48-72 hours. This is due to high levels of prostaglandins that cause contraction in the myometrium. The incidence of dysmenorrhea in Indonesia is $64.25 \%$, which $54.89 \%$ has primary dysmenorrhea while $9.36 \%$ has secondary dysmenorrhea. In principle there are two therapies for treatment of primary dysmenorrhea that is pharmacological and non-pharmacological. Cow milk is a food that containing high calcium and can be used as one of the non-pharmacological therapy to reduce pain intensity of primary dysmenorrhea. This study aims to determine the influence of cow milk consumption to decrease the pain intensity of primary dysmenorrhea in students of nursing department at SMKN 2 Malang. The research design used was true experiment with pre test-post test with control group design. The sample in this study were 21 people and divided into three groups taken by simple random sampling. The results showed that there was a difference of decrease pain intensity in three groups using One Way Anova test with $p$ value 0.000 ( $p<0.005)$. The optimal dose can decrease pain intensity of primary dysmenorrhea is cow milk with $1000 \mathrm{mg}$ calcium which has the highest pain delta value of 4.57 compared with experimental group II and control group. So it can be concluded that the higher value of the delta pain then the greater the dose effect given to decreased pain intensity of primary dysmenorrhea.
\end{abstract}

Keywords: Primary Dysmenorrhea, Cow Milk, Calcium

\section{ABSTRAK}

Dismenore primer merupakan gangguan ginekologi yang umumnya terjadi pada remaja putri tanpa ditemukan adanya kondisi patologi. Rasa sakit dari dismenore primer biasanya dimulai dua hari sebelum menstruasi atau saat menstruasi dan bertahan hingga 48-72 jam. Hal ini disebabkan karena tingginya kadar prostaglandin yang menyebabkan 
kontraksi pada myometrium. Angka kejadian dismenore di Indonesia sebanyak $64.25 \%$, $54.89 \%$ diantaranya mengalami dismenore primer sedangkan $9.36 \%$ mengalami dismenore sekunder. Pada prinsipnya terdapat dua terapi untuk penanganan dismenore primer yaitu secara farmakologi dan non farmakologi. Susu sapi merupakan bahan makanan yang mengandung tinggi kalsium yang dapat dijadikan sebagai salah satu terapi secara non farmakologi untuk menurunkan intensitas nyeri dismenore primer. Penelitian ini bertujuan untuk mengetahui adanya pengaruh konsumsi susu sapi terhadap penurunan intensitas nyeri dismenore primer pada siswi jurusan keperawatan di SMKN 2 Malang. Desain penelitian yang digunakan adalah true eksperimen dengan rancangan pre test-post test with control group design. Hasil penelitian menunjukkan terdapat perbedaan penurunan intensitas nyeri pada ketiga kelompok penelitian menggunakan uji One Way Anova dengan angka signifikansi sebesar $0.000(p<0.005)$. Dosis optimal yang dapat menurunkan intensitas nyeri dismenore primer adalah susu sapi dengan kandungan 1000 mg kalsium yang memiliki nilai delta nyeri tertinggi sebesar 4.57 dibandingkan dengan kelompok eksperimental II maupun kelompok kontrol. Sehingga dapat disimpulkan bahwa semakin tinggi nilai delta nyeri maka semakin besar pengaruh dosis yang diberikan terhadap penurunan intensitas nyeri dismenore primer.

Kata kunci: Dismenore Primer, Susu Sapi, Kalsium

*Korespondensi: Devi Febriani. Surel: febrianidevi13296@gmail.com 


\section{PENDAHULUAN}

Dismenore primer mengacu pada nyeri haid tanpa ditemukan adanya kondisi patologi pada panggul. Rasa sakit dari dismenore primer biasanya dimulai dua hari sebelum menstruasi atau saat terjadinya periode menstruasi dan bertahan hingga 48-72 jam. Hal ini disebabkan karena senyawa prostaglandin yang menyebabkan kontraksi pada myometrium [1]. Angka kejadian dismenore di Negara Indonesia sebanyak $64.25 \%$, yang mana $54.89 \%$ diantaranya mengalami dismenore primer dan $9.36 \%$ mengalami dismenore sekunder ${ }^{[2]}$.

Berbagai teknik telah banyak digunakan untuk mengatasi nyeri saat menstruasi, termasuk obat-obatan jenis Non-Steroidal Anti Inflammatory Drugs (NSAIDs), penggunaan kontrasepsi (pil kontrasepsi oral kombinasi dan DMPA), dan analgesik, yang menunjukan tingkat kegagalan sebanyak $25 \%$ dalam pengelolaan nyeri. Penggunaan obat dalam jangka panjang dapat menimbulkan beberapa efek samping, seperti mual, dispepsia, ulkus, peptik dan diare. Kesulitan dalam pengelolaan dismenore dapat menyebabkan peningkatan resiko nyeri [3]. Studi terbaru menunjukkan berbagai macam kandungan nutrisi menjadi salah satu fokus dalam sejumlah penelitian yang memberikan efek menguntungkan pada wanita yang mengalami dismenore primer salah satunya yaitu kalsium $^{[1]}$.

Sumber utama kalsium dalam makanan terdapat pada susu dan berbagai produk olahanya, seperti keju dan yoghurt ${ }^{[4]}$. Selain kandungan kalsiumnya yang tinggi, susu sapi merupakan salah satu bahan makanan yang mengandung zat makronutrient dan zat mikronutrient yang dibutuhkan oleh tubuh. Selain kandungan nutrisinya yang ideal dalam masa pertumbuhan, semua zat gizi yang terkandung di dalam susu sapi berperan penting dalam pengaturan fisiologis seorang wanita menjelang menstruasi dan saat menstruasi ${ }^{[5]}$.

Tingginya prevalensi dismenore primer pada remaja putri disebabkan karena sebagian besar penduduk dunia tidak memenuhi kebutuhan kalsium mereka yang banyak ditemukan dalam satu jenis makanan yaitu susu sapi ${ }^{[6]}$. Data konsumsi susu sapi per kapita pada masyarakat Indonesia yang diambil pada tahun 2016 jauh lebih rendah dibandingkan dengan Negara ASEAN lainya (Indonesia: 14.3 liter; Filipina: 22.1 liter; Malaysia 50.9 liter; dan Thailand 33.7 liter) ${ }^{[7]}$.

Menurut Lavon Dunne dalam Nutrition Almanac pada tahun 2002, untuk dapat menurunkan nyeri saat dismenore diperlukan kalsium sejumlah 800-1.000 mg, dengan cara dikonsumsi sebanyak 250-500 mg setiap 4 jam sekali saat merasakan nyeri [8]. Sedangkan menurut penelitian lain menyatakan dengan mengonsumsi suplementasi kalsium sebanyak 1.000 mg per hari terbukti efektif dalam mengurangi intensitas nyeri akibat dismenore primer dibandingkan dengan mengonsumsi kombinasi suplemen dari kalsium dan vitamin $D$ [9]. Para peneliti meyakini bahwa kalsium memainkan peran dalam mengurangi rasa sakit saat dismenore dengan mengontrol aktifitas neuromuscular pada rahim akibat prostaglandin yang berlebihan. Sebaliknya, penurunan konsentrasi intake kalsium dapat meningkatkan kejang dan kontraksi otot pada rahim yang mengakibatkan berkurangnya suplai darah menuju ke rahim saat menstruasi sehingga menyebabkan nyeri ${ }^{[6]}$. 
Berdasarkan studi pendahuluan yang dilakukan tanggal 12 Mei 2017 pada siswi kelas $X$ jurusan keperawatan di SMKN 2 Malang tahun ajaran 2016/ 2017, dari 32 siswi terdapat 23 siswi yang mengalami dismenore primer. Dari 23 siswi yang mengalaminya, hanya 5 siswi yang memeriksakan diri ke fasilitas kesehatan, 7 siswi hanya beristirahat atau tidur selama merasakan nyeri, 5 siswi mengonsumsi obat pereda rasa nyeri dan jamu, 1 siswi menggunakan kompres air hangat pada perut bagian bawah dan 10 siswi lainnya hanya membiarkan rasa nyeri tersebut sampai hilang dengan sendirinya [10]. Berdasarkan latar belakang yang telah dipaparkan, maka peneliti tertarik untuk menganalisa pengaruh dari konsumsi susu sapi terhadap penurunan intensitas nyeri dismenore primer pada siswi jurusan keperawatan di SMKN 2 Malang.

\section{METODE PENELITIAN}

\section{Rancangan/Desain Penelitian}

Desain penelitian yang digunakan yaitu true eksperiment dengan menggunakan rancangan Pre Test-Post Test With Control Group Design.

\section{Sumber Data}

Sumber data pada penelitian ini didapatkan dari pengukuran intensitas nyeri sebelum dan setelah delapan jam intervensi menggunakan skala nyeri NRS. Sebelum pemberian intervensi dilakukan pencatatan menggunakan lembar SQ-FFQ untuk mengetahui asupan kalsium responden selama satu bulan terakhir. Penelitian ini dilakukan dari bulan Desember 2017 hingga Januari 2018.

\section{Sasaran Penelitian}

Penelitian ini dilakukan pada siswi kelas $X$ jurusan keperawatan di SMKN 2 Malang tahun ajaran 2017/ 2018 berusia 15-16 tahun yang mengalami dismenore primer. Jumlah populasi pada penelitian ini sebanyak 131 siswi. Jumlah siswi yang menjadi sampel dalam penelitian ini sebanyak 21 orang. Sampel yang terpilih akan dibagi menjadi 3 kelompok, yaitu kelompok eksperimental I, kelompok eksperimental II, dan kelompok kontrol melalui teknik Simple Random Sampling.

\section{Pengembangan Instrumen dan Teknik Pengumpulan Data}

Instrumen penelitian yang digunakan pada penelitian ini yaitu susu sapi bubuk merk "Hilo Teen High Calcium" rendah lemak, wadah minuman dan sedotan berbahan dasar plastik, timbangan digital, air mineral merk "AQUA", termometer aksila, lembar informed consent, kuisioner pemilihan sampel, kuisioner karakteristik responden, lembar identifikasi responden, lembar SQ$F F Q$, lembar observasi pengukuran intensitas nyeri menggunakan NRS.

Teknik pengambilan data dalam penelitian ini yaitu dimulai dengan mencari responden yang sesuai dengan kriteria inklusi maupun eksklusi dengan menggunakan kuisioner pemilihan sampel. Kemudian peneliti memberikan penjelasan terkait tujuan, manfaat dan prosedur penelitian kepada calon responden serta memberikan lembar informed consent untuk diserahkan dan ditandatangani oleh orang tua. Setelah itu sampel dibagi menjadi 3 kelompok penelitian yaitu kelompok eksperimental 1 yang mendapatkan susu sapi dengan kandungan kalsium $1000 \mathrm{mg}$, kelompok eksperimental 2 mendapatkan susu sapi dengan 
kandungan kalsium $800 \mathrm{mg}$, dan kelompok kontrol. Pada kelompok eksperimental susu sapi diberikan 2 kali dalam selang waktu 4 jam selama 8 jam waktu penelitian, sedangkan untuk kelompok kontrol diberikan susu sapi dengan jumlah yang sama dengan kelompok eksperimental 2 setelah 8 jam waktu penelitian terselesaikan untuk memenuhi unsur keadilan dalam penelitian ini. Sebelum pemberian intervensi dilakukan pencatatan menggunakan lembar SQ-FFQ untuk mengetahui asupan kalsium responden selama satu bulan terakhir yang dilakukan oleh enumerator dari mahasiswa jurusan gizi FKUB. Sebelum pengisian lembar pre test dilakukan pengisian lembar karakteristik dan lembar identifikasi responden yang diisi oleh peneliti Selanjutnya responden mengisi lembar pre test dengan melingkari angka yang dianggap mewakili nyeri dismenore primer yang dirasakannya dan diakhiri dengan pengisian lembar post test yang dilakukan 8 jam setelah intervensi.

\section{Teknik Analisis Data}

Pertama-tama dilakukan uji normalitas menggunakan uji Shapiro wilk yang biasa digunakan apabila sampelnya kurang dari 50 ( $p>0.05)$. Analisa deskriptif digunakan untuk melihat gambaran umum karakteristik responden. Untuk mengetahui perbedaan intensitas dismenore primer sebelum dan sesudah diberikan intervensi pada setiap kelompok penelitian menggunakan uji Paired $t$ test $(\mathrm{p}<0.05)$. Uji statistik One Way Anova digunakan untuk mengetahui yang masuk dalam kategori kurang yaitu $<1200 \mathrm{mg}$. perbedaan penurunan intensitas nyeri pada ketiga kelompok penelitian $(p<0.05)$. Hubungan pemberian susu sapi terhadap penurunan intensitas nyeri pada responden yang mengalami dismenore primer menggunakan uji statistik Pearson $(\mathrm{p}<0.05)$. sedangkan untuk mengetahui seberapa besar pengaruh konsumsi susu sapi terhadap penurunan intensitas nyeri dismenore primer menggunakan uji linear regresi.

\section{HASIL PENELITIAN}

Jumlah responden dalam penelitian ini sebanyak 21 orang dan terbagi menjadi 3 kelompok yaitu kelompok eksperimental I, kelompok eksperimental II, dan kelompok kontrol yang masing-masing kelompok terdiri dari 7 responden.

\section{Karakteristik Responden}

Usia responden pada kelompok eksperimental I, eksperimental 2 maupun kelompok kontrol berkisar antara 15-16 tahun. Untuk usia menarch responden pada kelompok eksperimental I dan kelompok kontrol paling banyak pada rentang usia 13-15 tahun, sedangkan pada kelompok eksperimental II paling banyak pada rentang usia 10-12 tahun. Terkait lama menstruasi responden semuanya masih tergolong normal dan pada ketiga kelompok mayoritas lama menstruasi terjadi selama 7-8 hari. Untuk hasil analisa SQ-FFQ menggunakan nutri survey terkait asupan kalsium responden selama satu bulan terakhir didapatkan hasil bahwa semua responden dalam penelitian ini memiliki asupan kalsium

\section{Gambaran Intensitas Nyeri Dismenore Primer Setiap Kelompok Penelitian}

Gambaran intensitas nyeri dismenore primer pada kelompok 
eksperimental I mengalami penurunan antara sebelum dan sesudah diberikan intervensi, yang sebelumnya responden merasakan nyeri dalam kategori nyeri sedang sampai berat menjadi tidak nyeri sampai nyeri ringan. Pada kelompok eksperimental II juga mengalami penurunan intensitas nyeri antara sebelum dan sesudah diberikan intervensi. Namun berbeda penurunannya dengan kelompok eksperimental I, yang sebelumnya responden merasakan nyeri dalam kategori nyeri ringan sampai nyeri berat menjadi nyeri ringan sampai sedang. Sedangkan pada kelompok kontrol yang tidak mendapatkan intervensi apapun selama 8 jam penelitian, gambaran intensitas nyeri dismenore primer sebelumnya berada dalam kategori nyeri ringan sampai nyeri berat meningkat menjadi nyeri sedang sampai berat.

\section{Perbedaan Penurunan Intensitas Nyeri Sebelum dan Sesudah Diberikan Perlakuan}

Pada penelitian ini hasil uji statistik Shapiro wilk menunjukkan angka signifikasi sebesar 0.177 yang artinya data yang didapatkan terdistribusi normal $(p>0.05)$. Selanjutkan dilakukan uji homogenitas variasi untuk menentukan homogenitas dari populasi data. Pada penelitian ini diperoleh angka signifikansi sebesar 0.298 yang artinya data telah memiliki variasi yang homogen $(p>0.05)$. Hasil uji Paired t-test kelompok eksperimental I dan kelompok eksperimental II didapatkan hasil perbedaan intensitas nyeri yang signifikan antara sebelum dan sesudah diberikan intervensi dengan nilai signifikansi sebesar $0.000(p<0.05)$, sedangkan untuk kelompok kontrol tidak ada perbedaan intensitas nyeri yang signifikan antara hasil pre test maupun post test dengan nilai signifikansi 0.61.

Berdasarkan uji One Way Anova menunjukkan angka signifikansi sebesar 0.000 yang artinya terdapat perbedaan penurunan intensitas nyeri pada ketiga kelompok $(p<0.05)$. Dapat disimpulkan bahwa konsumsi susu sapi dengan kandungan kalsium yang berbeda dapat memberikan perbedaan yang signifikan dalam menurunkan intensitas nyeri dismenore primer pada remaja putri.

Hasil dari uji post hoc didapatkan bahwa terdapat perbedaan yang bermakna antara kelompok kontrol dengan kelompok eksperimental I yang mendapatkan susu sapi dengan kandungan kalsium sebesar $1000 \mathrm{mg}$ dengan angka signifkansi sebesar $\mathrm{P}=0.000$, sedangkan antara kelompok kontrol dengan kelompok eksperimental II yang mendapatkan susu sapi dengan kandungan kalsium sebanyak $800 \mathrm{mg}$ menunjukkan angka signifikansi sebesar $\mathrm{P}=0.81$ yang artinya tidak terdapat perbedaan yang bermakna antara kedua kelompok tersebut. Untuk kelompok eksperimental I dan kelompok eksperimental II didapatkan hasil signifikansi sebesar $P=0.028$ yang artinya terdapat perbedaan yang bermakna antara keduannya.

\section{Hasil Uji Korelasi Pearson}

Berdasarkan uji korelasi pearson didapatkan hasil bahwa nilai signifikansi sebesar 0.000 dengan koefisien korelasi 0.713. Maka dapat disimpulkan terdapat hubungan signifikansi yang kuat antara konsumsi susu sapi dengan penurunan intensitas nyeri dismenore primer. Hal tersebut dapat diartikan semakin besar pemberian dosis susu sapi, maka semakin besar juga penurunan 
intensitas nyeri akibat dismenore primer tersebut.

\section{Hasil Uji Linear Regresi}

Berdasarkan hasil uji linear regresi didapatkan R-square sebesar 0.509 dan nilai koefisien determinasi (KD) sebesar $50.9 \%$. Hal tersebut menunjukkan bahwa penurunan nyeri dismenore primer $50.9 \%$ dipengaruhi oleh konsumsi susu sapi yang diberikan oleh peneliti.

Tabel 1. Karakteristik Responden

\begin{tabular}{|c|c|c|c|c|c|c|}
\hline \multirow[t]{2}{*}{$\begin{array}{l}\text { Karakteristik } \\
\text { Responden }\end{array}$} & \multicolumn{2}{|c|}{$\begin{array}{c}\text { Kelompok } \\
\text { eksperimental I } \\
N=7\end{array}$} & \multicolumn{2}{|c|}{$\begin{array}{c}\text { Kelompok } \\
\text { eksperimental II } \\
\mathrm{N}=7\end{array}$} & \multicolumn{2}{|c|}{$\begin{array}{c}\text { Kelompok Kontrol } \\
\mathrm{N}=7\end{array}$} \\
\hline & $\mathbf{N}$ & $\%$ & $\mathbf{N}$ & $\%$ & $\mathbf{N}$ & $\%$ \\
\hline \multicolumn{7}{|c|}{ Kategori Kelompok Umur } \\
\hline 15 tahun & 4 & 57.14 & 2 & 28.57 & 2 & 28.57 \\
\hline 16 tahun & 3 & 42.86 & 5 & 71.43 & 5 & 71.43 \\
\hline \multicolumn{7}{|l|}{ Usia Menarch } \\
\hline $10-12$ tahun & 3 & 42.86 & 6 & 85.71 & 3 & 42.86 \\
\hline 13-15 tahun & 4 & 57.14 & 1 & 14.28 & 4 & 57.14 \\
\hline \multicolumn{7}{|l|}{ Lama menstruasi } \\
\hline $5-6$ hari & 3 & 42.86 & 2 & 28.57 & 3 & 42.86 \\
\hline 7-8 hari & 4 & 57.14 & 5 & 71.43 & 4 & 57.14 \\
\hline \multicolumn{7}{|l|}{ Siklus Menstruasi } \\
\hline $23-33$ & 5 & $\overline{71.43}$ & 6 & 85.71 & 5 & $\overline{71.43}$ \\
\hline $34-44$ & 2 & 28.57 & 1 & 14.28 & 2 & 28.57 \\
\hline \multicolumn{7}{|l|}{ Asupan Kalsium } \\
\hline $\begin{array}{l}\text { Kurang }(<1200 \mathrm{mg}) \\
\text { Cukup }(1200 \mathrm{mg}) \\
\text { Lebih ( } 1200 \mathrm{mq})\end{array}$ & 7 & 100 & 7 & 100 & 7 & 100 \\
\hline
\end{tabular}

Tabel 2. Gambaran Intensitas Nyeri Dismenore Primer

\begin{tabular}{|c|c|c|c|c|c|c|c|c|c|c|c|c|}
\hline \multirow{4}{*}{ Tingkatan Nyeri } & \multicolumn{12}{|c|}{ Hasil Pengukuran } \\
\hline & \multicolumn{4}{|c|}{$\begin{array}{c}\text { Kelompok } \\
\text { eksperimental I N=7 }\end{array}$} & \multicolumn{4}{|c|}{$\begin{array}{c}\text { Kelompok } \\
\text { eksperimental II } \\
\mathrm{N}=7\end{array}$} & \multicolumn{4}{|c|}{$\begin{array}{c}\text { Kelompok Kontrol } \\
\mathrm{N}=7\end{array}$} \\
\hline & \multicolumn{2}{|c|}{ Sebelum } & \multicolumn{2}{|c|}{ Sesudah } & \multicolumn{2}{|c|}{ Sebelum } & \multicolumn{2}{|c|}{ Sesudah } & \multicolumn{2}{|c|}{ Sebelum } & \multicolumn{2}{|c|}{ Sesudah } \\
\hline & $\mathbf{N}$ & $\%$ & $\mathbf{N}$ & $\%$ & $\mathbf{N}$ & $\%$ & $\mathbf{N}$ & $\%$ & $\mathbf{N}$ & $\%$ & $\mathbf{N}$ & $\%$ \\
\hline Tidak Nyeri (0) & & & 1 & 14.29 & & & & & & & & \\
\hline Nyeri Ringan (1-3) & & & 6 & 85.71 & 1 & 14.29 & 5 & 71.43 & 2 & 28.57 & & \\
\hline Nyeri Sedang (4-6) & 5 & 71.43 & & & 2 & 28.57 & 2 & 28.57 & 2 & 28.57 & 6 & 85.71 \\
\hline Nyeri Berat (7-9) & 2 & 28.57 & & & 4 & 57.14 & & & 3 & 42.86 & 1 & 14.28 \\
\hline $\begin{array}{l}\text { Nyeri Sangat Berat } \\
\text { (10) }\end{array}$ & & & & & & & & & & & & \\
\hline
\end{tabular}


Tabel 3. Perbedaan Penurunan Intensitas Nyeri Sebelum dan Sesudah Perlakuan

\begin{tabular}{|c|c|c|c|c|c|c|c|c|c|c|c|c|}
\hline \multicolumn{4}{|c|}{ Kelompok eksperimental I } & \multicolumn{4}{|c|}{ Kelompok eksperimental II } & \multicolumn{4}{|c|}{ Kelompok Kontrol } & \multirow[b]{3}{*}{$\begin{array}{c}p- \\
\text { value }\end{array}$} \\
\hline \multicolumn{2}{|c|}{ Intensitas nyeri } & \multirow[b]{2}{*}{$\begin{array}{l}\text { Delta } \\
\text { nyeri }\end{array}$} & \multirow{2}{*}{$\begin{array}{c}\mathrm{p}- \\
\text { value }\end{array}$} & \multicolumn{2}{|c|}{ Intensitas nyeri } & \multirow[b]{2}{*}{$\begin{array}{l}\text { Delta } \\
\text { nyeri }\end{array}$} & \multirow{2}{*}{$\begin{array}{c}\mathrm{p}- \\
\text { value }\end{array}$} & \multicolumn{2}{|c|}{ Intensitas nyeri } & \multirow[b]{2}{*}{$\begin{array}{l}\text { Delta } \\
\text { nyeri }\end{array}$} & \multirow{2}{*}{$\begin{array}{c}p- \\
\text { value }\end{array}$} & \\
\hline $\begin{array}{l}\text { Sebelum } \\
(x \pm S D)\end{array}$ & $\begin{array}{l}\text { Sesudah } \\
(x \pm S D)\end{array}$ & & & $\begin{array}{l}\text { Sebelum } \\
(x \pm S D)\end{array}$ & $\begin{array}{l}\text { Sesudah } \\
(x \pm S D)\end{array}$ & & & $\begin{array}{l}\text { Sebelum } \\
(x \pm S D)\end{array}$ & $\begin{array}{l}\text { Sesudah } \\
(x \pm S D)\end{array}$ & & & \\
\hline $\begin{array}{l}6.00 \pm \\
1.52\end{array}$ & $\begin{array}{l}1.43 \pm \\
0.78\end{array}$ & 4.57 & $0.00^{\mathrm{a}}$ & $\begin{array}{l}5.00 \pm \\
1.52\end{array}$ & $\begin{array}{l}2.71 \pm \\
1.70\end{array}$ & 2.29 & $0.00^{\mathrm{a}}$ & $\begin{array}{c}5.86 \pm \\
2.11\end{array}$ & $\begin{array}{c}5.43 \pm \\
0,78\end{array}$ & 0.43 & $0.61^{a}$ & $0.00^{\mathrm{b}}$ \\
\hline
\end{tabular}

Keterangan: a: Paired t-test, b: One Way Anova

PEMBAHASAN

\section{Karakteristik Penelitian \\ Responden}

Karakteristik responden yang mengalami dismenore primer dalam penelitian ini merupakan remaja putri yang berusia 15-16 tahun dengan total responden sebanyak 21 orang. Berdasarkan hasil penelitian yang telah dilakukan pada siswi jurusan keperawatan di SMKN 2 Malang didapatkan responden yang berusia 15 tahun sebanyak 7 orang (33.3\%) sedangkan usia 16 tahun sebanyak 14 orang (66.6\%). Rata-rata usia responden pada kelompok eksperimental I yaitu 15.57 tahun, sedangkan pada kelompok eksperimental II dan kelompok kontrol rata-rata usia responden sama yaitu 15.71 tahun. Pada usia 15-16 tahun dismenore primer umum terjadi hal ini disebabkan karena dimulainya dismenore primer 2 sampai 3 tahun setelah menarch, ketika sebagian besar remaja putri sudah mencapai siklus ovulasi mereka [11]. Puncak dismenore primer terjadi pada remaja akhir yaitu pada usia 20 , dan prevalensi ini akan menurun seiring dengan bertambahnya usia [12]. Pada wanita yang belum pernah hamil sebelumnya (nullipara) memiliki resiko lebih besar untuk mengalami dismenore primer dari pada multipara. Hal ini disebabkan karena pada nullipara kadar prostaglandin yang dilepaskan oleh endometrium saat menstruasi lebih tinggi daripada multipara ${ }^{[13]}$.

Pada penelitian ini usia menarch responden paling banyak terjadi pada rentang usia 10 sampai 12 tahun yaitu sebanyak 12 orang, sedangkan untuk usia menarch 13 sampai 15 tahun sebanyak 9 orang. Hal ini sejalan dengan penelitian yang dilakukan oleh Gustina (2015) yang menyatakan bahwa usia responden yang mengalami usia menarch paling banyak yaitu usia $<12$ tahun ${ }^{[14]}$. Menarch merupakan indeks dari pematangan fisik dari organ reproduksi seorang wanita. Penelitian menunjukkan bahwa usia dini saat menarch yaitu usia $<13$ tahun merupakan faktor resiko penting dari dismenore primer ${ }^{[13]}$. Hal ini didasari karena remaja putri yang mengalami menarch lebih awal akan memiliki keterpaparan yang lebih lama terhadap prostaglandin yang dihasilkan oleh endometrium saat menstruasi. Lama menstruasi responden pada penelitian ini paling banyak terjadi ' $7-8$ hari sejumlah 13 orang, sedangkan 5-6 hari sejumlah 
8 orang. Remaja putri dengan lama menstruasi lebih dari 5 hari memiliki resiko 1.9 kali lebih tinggi untuk mengalami dismenore. Semakin lama menstruasi, maka semakin sering uterus berkontraksi akibatnya semakin banyak pula prostaglandin yang dihasilkan sehingga timbul rasa nyeri saat menstruasi ${ }^{[12]}$.

\section{Intensitas Nyeri Dismenore Primer Sebelum Diberikan Susu Sapi Pada Setiap Kelompok Penelitian}

Nyeri dismenore primer yang dirasakan oleh remaja putri menyebabkan ketidaknyamanan tersendiri bagi mereka sehingga mengurangi kualitas hidup dan mengganggu aktifitas sehari-hari. Berdasarkan tabel 5.2 didapatkan bahwa sebelum diberikan susu sapi sebagian besar responden mengalami nyeri sedang sampai berat sebanyak 9 orang (42.86\%), dan nyeri ringan 3 orang (14.29\%). Perbedaan intensitas nyeri yang dirasakan disebabkan oleh perbedaan waktu terjadinya dismenore primer pada masingmasing responden. Nyeri dismenore primer paling dirasakan pada 24-36 jam pertama saat menstruasi. Hal ini sesuai dengan waktu terjadinya pelepasan prostaglandin yang maksimal oleh rahim ${ }^{[6]}$. Pada wanita yang mengalami dismenore primer terjadi peningkatan kepekaan nyeri pada bagian tubuh tertentu dibandingkan dengan wanita yang tidak mengalaminya ${ }^{[15]}$. Perbedaan persepsi nyeri yang dialami seseorang juga dapat mempengaruhi tingkat nyeri yang dirasakan oleh responden. Hal ini disebabkan oleh beberapa kondisi diantaranya kecemasan, depresi, pengalaman nyeri terdahulu, usia dan jenis kelamin ${ }^{[16]}$.

\section{Pengaruh Konsumsi Susu Sapi Terhadap Penurunan Intensitas Nyeri Dismenore Primer Pada Remaja Putri}

Penelitian ini dilakukan untuk mengetahui pengaruh konsumsi susu sapi pada penurunan intensitas nyeri dismenore primer. Hasil penelitian menunjukkan bahwa konsumsi susu sapi dengan kandungan kalsium 1000 mg yang diberikan 2 kali dalam rentang waktu 4 jam sekali selama 8 jam waktu penelitian terbukti paling efektif untuk mengurangi intensitas nyeri dismenore primer. Hal ini dibuktikan dengan hasil delta nyeri tertinggi pada kelompok eksperimental I yang mendapatkan susu sapi dengan kandungan kalsium 1000 mg yaitu sebesar 4.57, karena semakin besar nilai delta nyeri maka semakin besar pula pengaruh yang diberikan dosis untuk menurunkan intensitas nyeri dismenore primer.

Dismenore primer merupakan masalah yang paling umum terjadi pada $20 \%$ sampai $90 \%$ remaja dan wanita muda dengan siklus ovulasi normal dan tidak ditemukan adanya kondisi patologi pada pelvis. Pengobatan yang paling umum untuk menghilangkan dismenore primer adalah penggunaan obat NSAID. Namun penggunaan obat NSAID menunjukkan angka kegagalan sekitar $20 \%$ sampai $25 \%$ dan untuk pemakaian jangka panjang akan menimbulkan efek samping bagi pemakainya ${ }^{[17]}$. Efek yang ditimbulkan antara lain mual, dispepsia, ulkus, peptik dan diare. Oleh karena itu banyak penelitian mencari alternative yang tepat dan 
efektif untuk penangananan
dismenore primer

Nutrisi merupakan salah satu faktor terpenting yang mempengaruhi kualitas hidup seseorang. Kandungan nutrisi dan kondisi metabolisme seseorang memiliki peran yang penting untuk menangani gangguan menstruasi salah satunya nyeri saat menstruasi [17]. Berbagai macam kandungan nutrisi juga menjadi salah satu fokus dalam sejumlah penelitian yang memberikan efek menguntungkan pada wanita yang mengalami dismenore primer salah satunya yaitu kalsium [1]. Sumber utama kalsium dalam makanan terdapat pada susu dan berbagai produk olahanya, seperti keju dan yoghurt [4]. Selain kandungan kalsiumnya yang tinggi, susu sapi merupakan salah satu bahan makanan yang mengandung zat makronutrient dan zat mikronutrient yang dibutuhkan oleh tubuh. Banyak sekali manfaat yang diperoleh ketika seseorang mengkonsumsi susu secara rutin. Selain kandungan nutrisinya yang ideal dalam masa pertumbuhan, semua zat gizi yang terkandung di dalam susu sapi berperan penting dalam pengaturan fisiologis seorang wanita menjelang menstruasi dan saat menstruasi ${ }^{[5]}$. Pada penelitian yang dilakukan oleh Razzak et al (2010) menyatakan bahwa remaja putri yang mengonsumsi susu sapi tiga sampai empat kali per hari menunjukan resiko yang jauh lebih rendah mengalami dismenore primer ${ }^{[6]}$. Temuan awal penelitian ini menunjukan peran positif dari kalsium dalam pengelolaan dismenore primer, karena lebih dari $70 \%$ kalsium berasal dari produk susu. Pada wanita dengan intensitas nyeri dismenore yang sangat berat secara signifikan memiliki asupan kalsium dari produk susu yang rendah dibandingkan dengan wanita dengan intensitas nyeri dismenore primer yang berat [18].

Menurut Lavon Dunne dalam Nutrition Almanac pada tahun 2002, untuk dapat menurunkan nyeri saat dismenore diperlukan kalsium sejumlah 800-1.000 mg, dengan cara dikonsumsi sebanyak 250-500 mg setiap 4 jam sekali saat merasakan nyeri ${ }^{[8]}$. Persentase kalsium yang diserap tergantung pada jumlah total unsur kalsium yang dikonsumsi pada satu waktu. Semakin bertambahnya jumlah kalsium yang dikonsumsi maka efektifitas penyerapan kalsium akan menurun. Penyerapan tertinggi dalam dosis $\leq 500 \mathrm{mg}$. Jadi, seseorang yang mengonsumsi $1.000 \mathrm{mg} \mathrm{/} \mathrm{hari} \mathrm{kalsium} \mathrm{dari}$ suplemen bisa membagi dosis dan minum $500 \mathrm{mg}$ pada dua waktu terpisah [4]. Penelitian yang dilakukan oleh Susilowati (2014) yang menyatakan bahwa konsumsi susu sapi yang mengandung 1000 mg kalsium dapat menurunkan intensitas nyeri dismenore primer berdasarkan uji $t$-dependent didapatkan $p=0.002(p<0.05)$. Hal ini menunjukkan bahwa terdapat perbedaan yang signifikan antara sebelum dan sesudah diberikan intervensi berupa susu sapi pada remaja putri di SMAN 1 Unggaran [19]. Sedangkan menurut penelitian yang dilakukan oleh Zarei et al pada tahun 2017 mengenai Effects of Calcium-Vitamin $D$ and CalciumAlone on Pain Intensity and Menstrual Blood Loss in Women with Primary Dysmenorrhea menyatakan dengan mengonsumsi suplementasi kalsium saja sebanyak 
$1.000 \mathrm{mg}$ per hari terbukti efektif dalam mengurangi intensitas nyeri akibat dismenore primer dibandingkan dengan mengonsumsi kombinasi suplemen dari kalsium dan vitamin $D^{[9]}$.

Kalsium memainkan peran dalam mengurangi rasa nyeri saat dismenore dengan mengontrol aktifitas neuromuscular pada rahim akibat prostaglandin yang berlebihan. Sebaliknya, penurunan konsentrasi intake kalsium dapat meningkatkan rangsangan neuromuscular sehingga meningkatkan kejang dan kontraksi otot pada rahim. Akibatnya aliran darah menuju ke rahim berkurang saat menstruasi sehingga menyebabkan nyeri ${ }^{[6]}$. Sedangkan menurut Zarei et al (2017) kalsium mampu mengatur kemampuan sel otot dalam menerima rangsangan saraf, dan bisa dianggap sebagai stabilizer ${ }^{[9]}$. Defisiensi kalsium juga dapat menyebabkan peningkatan nyeri dan gejala pra-mesntruasi. Oleh karena itu dengan asupan kalsium yang cukup dapat mengurangi keparahan tingkat nyeri haid dan gejala yang timbul ${ }^{[9]}$. Hal ini sejalan dengan hasil penelitian yang dilakukan oleh Hidayati (2016) yang menyatakan bahwa terdapat hubungan yang signifikan antara asupan kalsium dengan kejadian dismenore pada siswi di SMK Batik 2 Surakarta melalui uji statistik menggunakan rank spearman dengan nilai $r=-0.415$ dan $p=0.000$ $(p<0.05)^{[20]}$. Rendahnya asupan kalsium pada remaja disebabkan oleh beberapa faktor, diantaranya perilaku dalam pemilihan makanan, pengaruh teman pergaulan, atau kebiasaan makan dalam keluarga. Pengetahuan mengenai kalsium yang cukup baik dapat berperan sebagai faktor pendukung atau penguat yang penting untuk perilaku yang baik mengenai asupan kalsium pada remaja. Meskipun demikian terdapat faktor internal lain yang juga turut mempengaruhi asupan kalsium pada remaja yaitu body image, pemilihan makanan dan konsep diri terhadap makanan tersebut ${ }^{21]}$.

Melihat kemampuan dari susu sapi yang mengandung tinggi kalsium dalam menurunkan intensitas nyeri dismenore primer maka dapat disimpukan bahwa dengan mengonsumsi susu sapi dapat dijadikan sebagai salah satu pilihan metode secara nonfarmakalogis yang aman dan efektif untuk menurunkan nyeri dismenore primer pada remaja putri.

\section{SIMPULAN}

1. Rata-rata intensitas nyeri pada siswi yang mengalami dismenore primer sebelum diberikan perlakuan pada kelompok eksperimental I sebesar 6.00, untuk kelompok eksperimental II sebesar 5.00 dan untuk kelompok kontrol sebesar 5.85.

2. Rata-rata intensitas nyeri pada siswi yang mengalami dismenore primer sesudah diberikan perlakuan pada kelompok eksperimental I sebesar 1.42, untuk kelompok eksperimental II sebesar 2.71, sedangkan untuk kelompok kontrol sebesar 5.42.

3. Perbedaan intensitas nyeri dismenore primer antara sebelum dan sesudah diberikan susu sapi pada kelompok eksperimental I yaitu sebesar 4.57, pada kelompok eksperimental II sebesar 2.29, sedangkan untuk kelompok kontrol sebesar 0.43 . 
4. Terdapat perbedaan penurunan intensitas nyeri dismenore primer pada ketiga kelompok penelitian yang diberikan susu sapi dengan kandungan kalsium yang berbeda berdasarkan hasil uji statistik One Way Anova dengan nilai signifikansi $\mathrm{p}=0.000$ $(p<0.005)$. Hasil uji post hoc menunjukkan terdapat perbedaan penurunan intensitas nyeri yang signifikan antara kelompok eksperimental I dengan kelompok kontrol dengan angka signifkansi sebesar $P=0.000$, sedangkan antara kelompok eksperimental I dan kelompok eksperimental II didapatkan hasil signifikansi sebesar $\mathrm{P}=0.028$ yang artinya terdapat perbedaan yang bermakna antara keduanya.

5. Terdapat hubungan antara konsumsi susu sapi dengan penurunan intensitas nyeri dismenore primer berdasarkan hasil uji korelasi pearson dengan angka signifikansi sebesar $\mathrm{p}=0.000$ dengan koefisien korelasi sebesar 0.713. Semakin besar pemberian dosis kalsium yang terkandung pada susu sapi maka semakin besar pengaruh yang diberikan dalam menurunkan intensitas nyeri dismenore primer.

6. Penurunan intensitas dismenore primer dipengaruhi oleh konsumsi susu sapi sebesar $50.9 \%$.

\section{Saran}

Saran yang dapat kami sampaikan untuk peneliti yang ingin membenahi ataupun melanjutkan penelitian ini yaitu sebaiknya menambahkan variabel lain yang menjadi faktor resiko terjadinya dismenore primer seperti faktor stress, indeks masa tubuh (IMT) dan aktifitas fisik responden. Selain itu perlu penelitian lebih lanjut untuk mengetahui seberapa lama pengaruh dari konsumsi susu sapi dalam menurunkan intensitas nyeri dismenore primer yang tidak bisa dilakukan dalam penelitian ini karena keterbatasan waktu yang dimiliki oleh peneliti.

\section{UCAPAN TERIMAKASIH}

Ucapan terimakasih
disampaikan kepada SMKN 2
Malang atas kesediaannya
menerima penulis untuk melakukan
penelitian.

\section{DAFTAR PUSTAKA}

[1] Preedy Victor R., Hunter Lan-Anh., Patel Vinood B. 2013. Diet Quality An Evidence - Based Approach Volume 1. Humana Press.

[2] Santoso. 2008. Angka Kejadian Nyeri Haid Pada Remaja Putri Di Indonesia. (online), (http://.infosehat.com/inside level2, diakses 24 Maret 2017.

[3] Uysal, Murat et al. Investigating The Effect of Rose Essential Oil in Patients with Primary Dysmenorrhea. Complementary Therapies in Clinical Practice, Vol. 24, August 2016, Pages 45-49.

[4] Ross, A Catharine et al. 2011. Dietary Reference Intake For Vitamn $D$ And Calcium. Washington, DC: National Academy Press.

[5] Devi, Nirmala. 2012. Gizi Saat Sindrom Menstruasi. Jakarta: PT Buana IImu Populer Kelompok Gramedia.

[6] Razzak- Abdul KK, Obeidat BA, Ayoub Nehad. Influence Of Dietary Intake Of Dairy Products On 
Dysmenorrhea. J. Obstet. Gynaecol. Res. Vol. 36, No. 2: 377-383, April 2010.

[7] Abdi, Ali. 2016. Indonesia 2016 Dairy And Product Annual Report. Gain Report: Jakarta.

[8] Dunne, J Lavon. 2002. Nutrition Almanac $5^{\text {th }}$ edition. McGraw-Hill Companies, Inc. All rights reserved. Manufactured in the United States of America.

[9] Zarei, Somayeh et al. Effects of Calcium-Vitamin D and CalciumAlone on Pain Intensity and Menstrual Blood Loss in Women with Primary Dysmenorrhea: A Randomized Controlled Trial. Pain Med. 2017 Jan 1;18(1):3-13

[10] Febriani, Devi. 2017. Pengaruh Konsumsi Susu Sapi Terhadap Penurunan Intensitas Nyeri Dismenore Primer Pada Siswi Jurusan Keperawatan Di SMKN 2 Malang. Skripsi. Tidak diterbitkan. Fakultas Kedokteran Universitas Brawijaya Malang.

[11] Harel Z. Dysmenorrhea in Adolescent and Young Adults: Etiology and Management. Pediatric Adolescent Gynecology, 2006, Vol 19 (363-371).

[12] Kural M.,Noor NN., Pandit D., Joshi T., Patil A. Menstrual Characteristics And Prevalence Of Dysmenorrhea In College Going Girls. J Family Med Prim Care. 2015 Jul-Sep; 4(3): 426-431.

[13] Hailemeskel Salomon., Demissie Asrate., Nigussie Assefa. Primary Dysmenorrhea Magnitude, Associated Risk Factors, And Its Effect On Academic Performance: Evidence From Female University Students In Ethiopia. International
Journal Womens Health. 2016; 8: 489-496.

[14] Gustina, Tina. 2015. Hubungan Antara Usia Menarche Dan Lama Menstruasi Dengan Kejadian Dismenore Primer Pada Remaja Putri Di SMKN 4 Surakarta. Tugas Akhir. Tidak Diterbitkan. Fakultas IImu Kesehatan Universitas Muhammadiyah Surakarta.

[15] Lacovides, Stella. Beker, Fiona C. Avidon Ingrid. Bentley Alison. Women With Dysmenorrhea Are Hypersensitive To Experimental Deep Muscle Pain Across The Menstrual Cycle. The Journal of Pain, Vol 14, No 10 (October), 2013: pp 1066-1076.

[16] Smeltzer, SC Dan Bare, BG. 2003. Brunner And Suddharth's Textbook Of Medical Urgical Nursing, 10 th Edition., Lippincott Williams And Wilkins, Philadelphia.

[17] Charandabi-Alizadeh., Mirghafourvand Mojgan., Chegini Nezamivand., Javadzadeh Yousef. Calcium With and Without Magnesium For Primary Dysmenorrhea: A Double-Blind Randomized Placebo-Controlled Trial. IJWHR Vol. 5, N0. 4, October 2017, 332-338.

[18] Razzak-Abdul KK, Obeidat BA, AlFarras MI, Dauod AS. Vitamin D And PTH Status Among Adolescent And Young Females With Severe Dysmenorrhea. Journal Pediatric Adolesc Gynecol 2014;27(2):78-82.

[19] Susilowati. 2014. Perbedaan Efektifitas Susu Dan Coklat Terhadap Penurunan Skala Nyeri Pada Remaja Putri Dismenore Di SMAN 1 Unggaran. Tugas Akhir. Tidak diterbitkan. Program Studi 
DIV Kebidanan STIKES Ngudi

Waluyo Unggaran.

[20] Hidayati-kartika Rohmah.,

Soviana., Mardiyati-Nur Lathifah.

Hubungan Antara Asupan Kalsium

Dengan Asupan Zat Besi Dengan

Kejadian Dismenore Pada Siswi Di

SMK Batik 2 Surakarta. Jurnal

Kesehatan, ISSN 1979-7621, Vol.

1, No. 2, Desember 2016.

[21] Fikawati, Sandra., Syafiq, Ahmad.,

Purpasari, Puri. Faktor-Faktor

Yang Berhubungan Dengan

Asupan Kalsium Pada Remaja

Dikota Bandung. Jurnal

Kedokteran Trisakti Universa

Medicina, Januari-Maret 2005-

Vol.24, No.1. 